\title{
Luteinizing Hormone (LH) pada Kerang Mutiara Jenis Pinctada maxima
}

\author{
Oleh: \\ Syachruddin AR
}

\begin{abstract}
ABSTRAK
Pinctada maxima merupakan jenis kerang mutiara yang dibudidayakan di NTB. Perubahan jenis kelamin atau fungsi gonadnya sangat ditentukan oleh faktor lingkungan (makanan) dan kemampuan metabolisme untuk menghasillkan energi atau protein serta hormon reproduksi (FSH atau LH) yang dihasilkan. Penelitian yang telah dilakukan pada tahun 1997 terhadap kadar LH dari 10 ekor kerang mutiara saat spawning dan seminggu setelah spawning yang menggunakan spektrofluorometri (TLC) dan analisa statitik dengan uji t. Hasilnya menunjukkan bahwa kadar LH (Luteinizing Hormone) sangat tinggi $(61,533 \mathrm{ppm} / \mathrm{cc})$ pada saat spawning, dan seminggu setelah spawning menurun menjadi $52,926 \mathrm{ppm} / \mathrm{cc}$. Indikasi ini menunjukkan bahwa kadar LH pada kerang mutiara dalam waktu 1 minggu mengalami penurunan yang sangat signifikan $(8,607 \mathrm{ppm} / \mathrm{cc})$ dengan $\mathrm{t}_{\text {hitung }}=5,10$ pada taraf signifikansi $5 \%$ dan $\mathrm{t}_{\text {tabel }}=4,03$. Penurunan ini kemungkinannya akan mencapai titik neutral. Hal ini menunjukkan bahwa kadar LH sangat menentukan pertumbuhan dan perkembangan gonad pada kerang mutiara.
\end{abstract}

Kata kunci : gonad, hormon, kadar, pemijahan.

\begin{abstract}
Pinctada maxima are oyster pearl of cultures in NTB. The sex or functional gonad change are the very heighten food factor in environment and the metabolism ability for hormone reproduction (FSH and LH). The research is already in 1997 year, tendency for to know LH grade spawning time and after spawning a week's to tail ten at oyster's pearl is same. The LH grades analysis use spektrofluorometri (TLC) and statistic analysis t test uses. That mother pearl oyster's at spawning time, LH (Luteinizing Hormone) grade the high production $(61.533 \mathrm{ppm} / \mathrm{cc})$ and grade happen the descending $52.926 \mathrm{ppm} / \mathrm{cc}$ after spawning a week's. The descend LH grade to pearl oysters is show that happen high signification $\left(8.607 \mathrm{ppm} / \mathrm{cc}\right.$ whit $t_{\text {calculate }}=5,10$ at $5 \%$ signification stage and $t_{\text {table }}=4,03$. The descending it's quite possible that reach neutral period. The high grading of LH a sure that indicate gonad growth of pearl oysters.

Key word: gonad, hormone, grade, spawning

\section{PENDAHULUAN}

$\mathrm{P}$ ertumbuhan dan perkembangan dari suatu individu menurut Chan (1949); Syachruddin dan Laba (2002) diatur dan dikendalikan oleh faktor genetik, sistim syaraf dan hormon. Aktivitas dan fungsi sel menurut Tun dan Tjahyo, (1998); Syachruddin (2002); Syachruddin (2009); Syachruddin (2011) tidak akan terarah

tanpa dikendalikan oleh gen dan koordinasi dari sistem syaraf dan hormon. Menurut Hafez (1980) dalam Mayes, et al. (1992), Sistem syaraf umumnya akan mengatur aktivitas alat-alat tubuh seperti : pergerakan otot dan sekresi kelenjar, sedangkan hormon mengatur aktivitas tubuh yang lambat mengalami perubahan, seperti : metabolisme, reproduksi, pertumbuhan dan
\end{abstract}


perkembangan. Tulisan ini hanya diarahkan pada kadar LH kerang mutiara saat spawning dan seminggu setelah spawning (pemijahan).

Hormon dihasilkan oleh kelenjar endokrin atau kelenjar buntu kemudian akan masuk ke dalam pembuluh darah melalui difusi. Menurut Mayes et al. (1992) dan Syachruddin, (1998) kadar hormon reproduksi tiap saat pada setiap individu tidak sama dan pengaruhnya dapat terjadi dalam beberapa detik, jam, hari, minggu, bulan bahkan tahunan. Fungsi hormon menurut Hafez (1980) dalam Mayes, et al. (1992), berkaitan erat dengan fungsi syaraf, karena pada beberapa kelenjar dapat bersekresi bila mendapat stimulus dari sistim syaraf seperti yang terjadi pada kelenjar adrenal bagian medulla dan neurohipofisa.

Gonad hewan dalam keadaan matang mengandung hormon reproduksi (LH dan atau FSH) (Wada and Wada, 1939 dan Syachruddin, 1998). Hasil penelitian ini menunjukkan bahwa kadar LH kerang mutiara penghasil spermia pada saat spawning, cukup tinggi $(61,533 \mathrm{ppm} / \mathrm{cc})$ dan seminggu setelah pemijahan terjadi penurunan yang cukup signifikan dan terjadi juga pada kerang mutiara penghasil ovum (Syachruddin, dkk., 2004). Fenomena ini memberikan gambaran bahwa kadar LH akan meningkat pada saat matang gonad dan menurun kembali pada saat sesudah memijah sampai pada tahap neutral. Manipulasi kadar LH yang diinjeksikan pada kerang mutiara neutral (tidak memiliki gamet) menurut Syachruddin (1998); Syachruddin (2006) dan Syachruddin (2009); dapat dilakukan sebagai stimulus agar kerang mutiara dapat menghasilkan spermia dan memacu percepatan pemijahan (spawning).

\section{METODE DAN BAHAN Pengambilan dan Perawatan Sampel}

Penelitian dilakukan pada tahun 1997 di Laboratorium LIPI Pemenang Lombok Utara Nusa Tenggara Barat (NTB) dan pengambilan cairan gonad kerang mutiara saat spawning dan seminggu sesudah spawning, dilakukan pada Bulan Juli Agustus tahun 1997 dan analisis sampel dilakukan pada laboratorium Analitik Universitas mataram.

Sampel cairan gonad disedot sebanyak 1 cc/induk saat spawning dan seminggu sesudah spawning dari 10 ekor induk kerang yang sama. Cairan gonad tersebut dimasukan dalam botol yang terpisah dan dilabel berdasarkan kelompok dan waktu pengambilannya, kemudian disimpan pada suhu dibawah $0{ }^{\circ} \mathrm{C}$ agar tidak mengalami kerusakan akibat aktivitas metabolisme maupun gangguan dari mikroorganisme.

\section{Ekstrak Sampel}

Prosedur analisis sampel (cairan gonad) terlebih dahulu dilarutkan dalam aquadest (pelarut LH) dan normal-hexan (pelarut lemak) serta fenol untuk menghilangkan protein, kemudian disentrifuge sekitar 10 menit untuk memisahkan antara cairan hormon dengan lemak dan protein sehingga cairan sampel terbentuk 3 (tiga) lapisan, yaitu: lapisan atas (air dan hormon), lapisan tengah (fenol dan protein), dan lapisan bawah (normalhexan dan lemak).

Lapisan atas di pipet untuk diencerkan dengan aquadest sebanyak 30 kali kemudian dianalisis kadar hormon (LH) dengan alat spektrofluorometri, menurut Soemadi (1991), melalui proses ini tahapan pemisahan dengan zat lain dapat diliwati, karena proses pemisahan yang panjang akan memperbesar koefisien variasi dan atau rikaveri. Kromatografi ini sekaligus dapat dilakukan pemisahan, 
identifikasi dan kuantitasi secara berurutan untuk LH dan FSH.

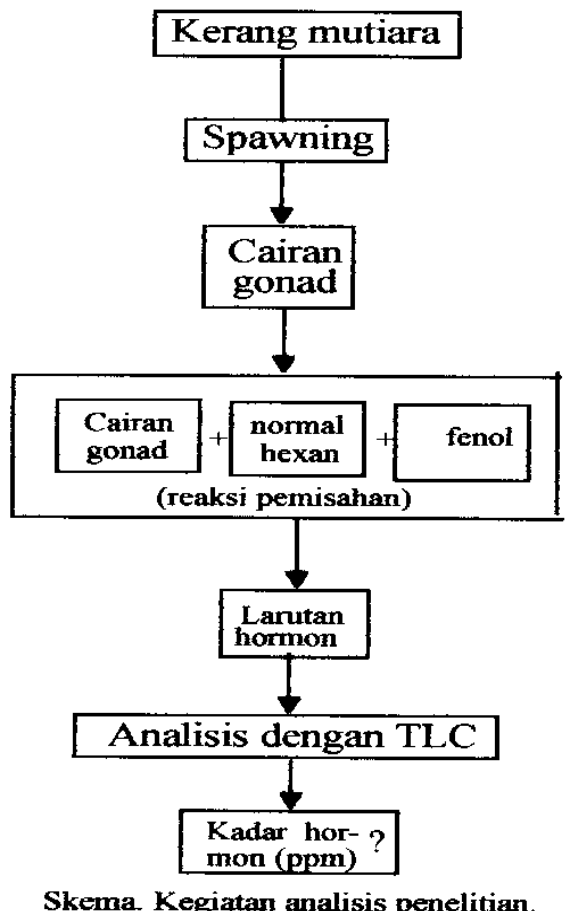

\section{HASIL DAN PEMBAHASAN}

Data yang diperoleh berdasarkan hasil analisis spekrofotometri dan perhitungannya serta hasil uji statistik

\section{Identifikasi dan Kuantitasi}

Identifikasi LH dalam cairan gonad dilakukan dengan TLC, karena hasilnya lebih baik dibandingkan dengan metode kromatografi lainnya. Identifikasi LH pada kerang mutiara saat dan post spawning dilakukan dengan urutan kegiatan analisis seperti pada skema kegiatan analisis sampel penelitian, adanya LH murni sebagai standar menurut Soebardi (1992) penggunaan metode kromatografi (TLC) secara langsung dapat memisahkan dan memurnikan LH sehingga identifikasi dan kuantitasi mudah dilakukan. Kuantitasi LH selanjutnya dihitung dengan menggunakan formula :

$\mathbf{L H}\left(\mathbf{C}_{\mathbf{L}}\right)$ adalah $\mathbf{A}=\mathfrak{£} \cdot \mathbf{b} \cdot \mathbf{C}_{\mathbf{L}}$ (Soemadi, 1991). Data kuantitas LH dianalisis secara statistik, menurut Sutrisno (1979), uji homogenitas sampel perlu dilakukan sebelum uji t dengan taraf signifikan $5 \%$ $(\alpha=0,05)$.

menurut Sutrisno (1979), dapat dilihat pada Tabel1berikut:

Tabel 1. Hasil analisis spekrofotometri dan perhitungannya serta hasil uji statistik

\begin{tabular}{crrl}
\hline \multirow{2}{*}{ Sempel } & \multicolumn{2}{c}{ Kadar LH (ppm/cc) } & \multicolumn{2}{c}{ Keterangan (hasil uji statistik) } \\
\cline { 2 - 3 } & Saat Spawning & Post Spwaning & $\mathrm{t}_{\text {tabel }}=\mathrm{F} \alpha 5 \%(\mathrm{NX} 1-1):(\mathrm{NX} 2-1)$ \\
$\mathbf{1}$ & 61,600 & 52,931 & $=0,975(9,9)=4.03$ \\
$\mathbf{2}$ & 61,500 & 52,947 & $\mathrm{t}_{\text {hitung }}=1.05 / 9 \times 9 / 0,06=9,45 / 0,54=5,10$ \\
$\mathbf{3}$ & 61,340 & 52,989 & $\mathrm{t}_{\text {tabel }}<\mathrm{t}_{\text {hitung }}(4,03<5,10)$, menunjukkan \\
$\mathbf{4}$ & 61,640 & 52,943 & kedua kelompok sampel heterogen. \\
$\mathbf{5}$ & 61,400 & 52,927 & Jadi: $\mathrm{t}_{\text {tabel }}<\mathrm{t}_{\text {hitung }}(4,03<5,10)$, berarti ada \\
$\mathbf{6}$ & 61,550 & 52,951 & perbedaan yang sangat signifikan antara \\
$\mathbf{7}$ & 61,640 & 52,985 & kadar LH pada kerang mutiara jenis \\
$\mathbf{8}$ & 61,680 & 52,928 & Pinctada maxima saat spawning dengan \\
$\mathbf{9}$ & 61,580 & 52,808 & kadar LH post spawning (seminggu \\
$\mathbf{1 0}$ & 61,400 & 52,851 & setelah pemijahan). Penurunan kadar LH- \\
Jumlah & 615,330 & 529,260 & nya mencapai 8,610 ppm/cc. \\
Rerata & 61,533 & 52,926 & \\
\hline
\end{tabular}




\section{Jenis kelamin kerang mutiara}

Pada umumnya Bivalvia menurut Dharma (1988) dan Sastry (1966), berjenis kelamin terpisah (dioecious) dan ada juga yang hermaprodit, tetapi Allan (1942), mengemukakan bahwa Pinctada maxima tergolong dioecious. Perubahan jenis kelamin atau fungsi gonad lebih banyak disebabkan oleh faktor makanan dan metabolisme, yaitu: bila jumlah konsumsi makanan banyak akan menjadi betina tetapi bila jumlah konsumsi makanan sedikit akan menjadi jantan. Disisi lain para ahli mengatakan bahwa metabolisme sangat menentukan arah fungsi gonad, yaitu: kemampuan metabolisme untuk menghasilkan protein yang tinggi akan menjadi betina tetapi bila kemampuan metabolisme untuk menghasilkan energi tinggi maka kerang mutiara akan menjadi jantan.

Gonad kerang mutiara jenis Pinctada maxima dapat menghasilkan ovum atau spermia pada saat yang berbeda. Perubahan fungsi ini menurut Tranter (1958) dan Mudasir (1981), disebabkan oleh faktor makanan, yaitu: saat persediaan makanan cukup tinggi akan menghasilkan ovum sedangkan pada saat persediaan makanan kurang akan menghasilkan spermia.

Membedakan jenis kelamin pada kerang mutiara tidak cukup hanya dilihat secara morfologis, tetapi harus diikuti dengan identifikasi warna gonadnya, namun para ahli masih berbeda pendapat dalam menggunakan warna gonad sebagai dasar untuk membedakan jenis kelamin. Warna gonad kerang mutiara menurut Herdman (1904), tidak dapat dijadikan dasar untuk membedakan jenis kelaminnya karena jantan dan betina pada saat tertentu gonadnya barwarna krem, tetapi menurut Tranter (1958), gonad kerang mutiara jantan berwarna lebih transparan atau putih dan betina bila gonadnya berwarna kekuning-kungingan atau kuning.
Didukung pula oleh hasil penelitian Syachruddin (1998), yang melakukan identifikasi warna gonad dan gametnya, menunjukkan bahwa warna gonad dapat dijadikan dasar untuk menentukan jenis kelamin, karena kerang mutiara yang memiliki spermia warna gonadnya putih seperti susu dan gonad kerang mutiara yang memiliki ovum berwarna kuning tua (krem).

Perbedaan pendapat antara Tranter dengan Herdman berdasarkan hasil pengamatan Syachruddin (1998), disebabkan oleh perbedaan waktu pengamatan, yaitu: Tranter mengamati warna gonad pada saat kerang mutiara memiliki gamet tertentu dalam gonadnya. Gamet-gamet tersebut akan mengarah pada warna yang berbeda yaitu : gonad yang memiliki spermatozoa warnanya putih sedangkan gonad mengandung ovum warnanya kuning (krem). Sedangkan Herdman (1904), mengamatinya pada saat kerang mutiara dalam masa transisi (neutral) yaitu: saat tidak memiliki gamet dalam gonadnya.

Pengamatan terhadap warna gonad secara teliti dapat dijadikan dasar untuk menentukan tingkat kematangan gamet, karena semakin jelas warna gonadnya maka semakin tinggi tingkat kematangan gamet yang terkandung didalamnya. Warna gonad yang semakin kuning mengandung ovum yang matang dengan kadar yolk yang tinggi dan gonad yang mengandung spermia yang matang akan semakin putih.

Puncak masa transisi (neutral) dari individu yang berubah fungsi gonadnya akan mengarah pada warna krem, sehingga Herdman (1904), menyimpulkan bahwa warna gonad tidak dapat dijadikan dasar untuk membedakan jenis kelamin pada kerang mutiara.

Hasil pengamatan Syachruddin dkk. (1994), dijumpai bahwa kerang mutiara secara morfolagis memiliki cangkang dan 
warna gonad yang berbeda antara jantan

pada Tabe 12 berikut:

dengan betina, perbedaannya dapat dilihat

Tabel 2. Perbandingan morfolagis cangkang dan warna gonad antara jantan dan betina

\begin{tabular}{|c|c|c|}
\hline No. & $\mathrm{J}$ a $\mathrm{nt}$ a $\mathrm{n}$ & B e t in a \\
\hline 1. & $\begin{array}{l}\text { Dua belah cangkang sama } \\
\text { besarnya }\end{array}$ & Salah satu cangkang lebih besar \\
\hline 2. & $\begin{array}{l}\text { Warna cangkang mulai dari } \\
\text { engsel (putih-pink-putih) }\end{array}$ & $\begin{array}{l}\text { Warnanya mulai dari engsel (pink- } \\
\text { hitam- pink-hitam) }\end{array}$ \\
\hline 3. & Dua belah cangkang agak rata & $\begin{array}{l}\text { Cangkang yang lebih besar agak } \\
\text { melengkung dan yang kecil agak rata. }\end{array}$ \\
\hline 4. & latif lebih besar & Ukurannya relatif lebih kecil \\
\hline 5. & Garis melintangnya tidak jelas & $\begin{array}{l}\text { Memiliki garis melintang yang sangat } \\
\text { jelas }\end{array}$ \\
\hline 6. & 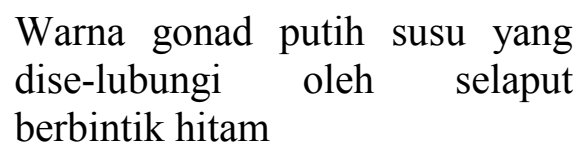 & $\begin{array}{l}\text { Gonadnya berwarna kuning yang dise- } \\
\text { lubungi oleh selaput yang berwarna } \\
\text { putih }\end{array}$ \\
\hline
\end{tabular}

Masa transisi (neutral) menurut Syachruddin (2002) merupakan saat yang paling tepat untuk mengarahkan fungsi gonad pada kerang mutiara melalui penerapan sistim hormonal, karena kadar hormon reproduksinya sangat rendah dibandingkan pada saat spawning. Stimulasi hormonal dengan menginjeksikan LH yang tepat menurut Syachruddin (1998), dapat mengarahkan fungsi gonad untuk menghasilkan ovum sehingga lebih cepat matang dan memijah.

\section{Hormon Reproduksi}

Pada tahun enampuluhan zat organik yang diproduksi oleh hipotalamus dan dapat merangsang kelenjar lain dan merangsang sel targetnya sehingga hormon dapat digunakan untuk "membangkitkan aktivitas" pada mahluk hidup. Fungsi hormon yang demikian memungkinkan bahwa hormon merupakan zat yang mengarahkan fungsi gonad pada kerang mutiara (Mayes, et al., 1992).

Hormon sebagai zat organik yang dihasilkan oleh sel-sel khusus dalam jumlah yang sangat sedikit dan dilepaskan pada saat yang tepat dengan kadar yang

tepat untuk organ sasarannya. Menurut Mayes, et al. (1992) hormon dapat bekerja pada sel penghasilnya (fungsi autokrin) dan sel yang berdekatan dengannya (fungsi parakrin). Hormon pada umumnya akan merangsang sel-sel tertentu dan berinteraksi dengan reseptor khusus pada sel target melalui peredaran darah menuju organ sasaran dan bekerja secara biokimia melalui dorongan atau hambatan dari kerja enzim.

Hormon menurut Hafez (1980) dalam Mayes, et al. (1992), tidak dapat bereaksi dan akan diubah oleh zat anti hormon dalam cairan tubuh sehingga akan mempengaruhi beberapa sel target yang berlainan tetapi dalam satu organ dapat bekerja lebih dari satu hormon bahkan hormon dapat mempengaruhi sistem syaraf atau sebaliknya. Di samping itu, tingkatan taksonomi hewan berpengaruh terhadap komplikasi kerja hormon, yaitu: makin rendah tingkat taksonominya makin sederhana sistim hormonnya dan semakin sederhana pula sistem kerjannya dan akan bekerjasama dengan syaraf dalam mengatur kegiatan organ tubuh dan akan 
mempengaruhi kerja enzim tertentu dalam tubuh. Fungsi organ menurut Turner, (1967) dan Soebadi (1992) akan terganggu, bila waktu dan kadarnya tidak tepat.

Kerang mutiara memiliki hormon reproduksi yang lebih sederhana dibandingkan dengan hewan tingkat tinggi. Hormon reproduksi pada kerang mutiara yang sudah terdeteksi adalah hormon LH dan FSH. Menurut Soebadi (1992), LH merupakan hormon glycoprotein, karena mengandung asam amino dan karbohidrat. Deretan asam amino dan karbohidratnya hampir serupa antara $\mathrm{LH}$ dengan $\mathrm{FSH}$, tetapi pada LH tidak mengandung Tryophan dan sangat sedikit mengandung asam sialat.

Hipofisa anterior dari betina, mengandung 2 (dua) gonadotropin yang berfungsi merangsang pematangan folikel dan merangsang pembentukan korpus luteum. Pemisahan LH dengan FSH dan perbedaan fungsi LH dilakukan oleh Long dan Evans tahun 1939 dalam Mayes, et al. (1992), yang mengembangkan teknik hipofisektomi sehingga didapatkan tikus yang tahan terhadap operasi hipofisektomi sehingga disebut strain Long Evans.

Perlakuan pembuangan kelenjar hipofisa pada tikus berumur 22 hari oleh Long Evans tahun 1939 dalam Mayes, et al. (1992), membaginya dalam 3 kelompok, yaitu: Group A, tidak diberikan perlakuan apapun kecuali hipofisektomi; Grup B, 12 hari setelah operasi, disuntik dengan preparat LH persubkutan $1 \mathrm{kali} / \mathrm{hari}$ selama 3 hari; Grup C, perlakuannya sama dengan grup B hanya preparat suntikannya adalah LH. Setelah 24 jam suntikan terakhir semua tikus dibunuh dan dibuat preparat histologi dari semua ovariumnya, ternyata hasilnya adalah: Grup A, ovariumnya keriput; Grup B, ovariumnya hampir normal besarnya dengan perkembangan sel-sel interstitial yang normal pula tetapi tidak folikelnya tidak mengalami perkembangan; Grup C, ovariumnya agak besar dengan perkembangan folikel yang agak menyolok jumlah dan besarnya.

Berdasarkan hasil penelitian tersebut dapat disimpulkan bahwa LH dapat digunakan untuk merangsang perkembangan gonad. Pada kerang mutiara LH dapat digunakan untuk merangsang perkembangan gonad penghasil spermia melalui suatu mekanisme yang belum terungkap sampai saat ini. LH diketahui pula dapat membantu perkembangan folikel hingga mencapai proses pematangan yang sempurna. Berarti LH dapat mempengaruhi sel-sel granulosa untuk produksi estrogen dalam folikel. Pada saat pematangan folikel mencapai titik maksimalnya menurut Mayes, et al. (1992), akan terjadi pelepasan LH (LH surger) yang menyebabkan terjadinya spawning (pemijahan).

Preparat hormon yang dicampur dengan penghancur asam sialat bila tidak berubah potensinya berarti mengandung LH, bila potensinya berubah berarti mengandung FSH. LH atau ICSH (Intestitial Cell Stimulating Hormon) merupakan glukoprotein yang mempunyai rantai asam amino berikatan peptida dan rantai karbohidrat yang berikatan polipeptida. Menurut Hafez (1980) dalam Mayes, et al. (1992), LH terdiri dari $\alpha-\mathrm{LH}$ yang mengandung 119 asam amino dan satu rantai kerbihidrat, dan $\beta$-LH yang mengandung 90 asam amino dan dua rantai karbohidrat.

Menurut Soebadi (1992), LH merupakan hormone glycoprotein karena mengandung 216 endapan asam amino dan karbohidrat sekitar 20\% dengan Berat Molekul 30.000. Deretan asam amino dan karbohidratnya hamper serupa dengan FSH tetapi LH tidak mengandung Tryophan dan sangat sedikit mengandung asam sialat. LH dihasilkan oleh sel basofil dari kelenjar 
hipofisa bagian anterior dengan sasaran utamanya adalah ovarium, testis, dan corpus luteum.

LH dapat merangsang sel-sel granulosa dan sel-sel theca pada folikel yang masak untuk memproduksi estrogen. Peningkatan kadar estrogen yang dihasilkan maka LH akan semakin tinggi sehingga folikel yang masak akan mengalami ovulasi. Selanjutnya LH bersama LTH akan merangsang sel-sel theca pada ruang bekas folikel yang pecah untuk membentuk selsel Korpus Luteum (KL) yang akan menghasilkan progesteron.

LH memiliki rantai karbohidrat terdiri dari monosakarida, yaitu: maltosa, galaktosa, fruktosa, $\mathrm{N}$-asetal glukosamine, $\mathrm{N}$-asetil galaktosa, fruktosamine dan asam sialat) yang berikatan membentuk inti polisakarida. Aktivitas biologisnya sangat tergantung pada asam sialat. LH dalam bentuk serbuk menurut Brander dan Pugh (1977) dalam Mayes, et al. (1992), berwarna putih, larut dalam air, stabil pada suhu kamar selama beberapa minggu, tetapi akan mengalami kerusakan bila terkena panas. Berat molekul dari masing-masing spesies berbeda. Penggunaan LH sebaiknya melalui injeksi karena larut dalam air dan rusak oleh enzim, kalau bercampur dengan protein lain biasanya disuntikan perintraperitoneal atau intra-muskuler. Variasi $\mathrm{pH}$ antara 4 - 11, kerusakan pada umumnya dipengaruhi oleh temperatur. Kadar LH dapat dihitung berdasarkan hasil analisis kromatografi dengan standar dan ketentuan sebagai berikut :

a. Penentuan harga absorbtivitas zat yang dianalisis, dapat dilakukan berdasarkan ketentuan pada standar ternyata $\mathrm{LH}$ berada pada pink $190 \mu \mathrm{m}$.

b. Penentuan kadar, kadar LH pada kerang mutiara (Pinctada maxima) saat spawning tinggi sekali $(61,533$ $\mathrm{ppm} / \mathrm{cc}$ ). Penurunan kadar LH yang cepat pada Pinctada maxima setelah seminggu pemijahan dari 61,533 $\mathrm{ppm} / \mathrm{cc}$ menjadi 52,926 $\mathrm{ppm} / \mathrm{cc}$ menurut Syachruddin (1998), akan terjadi sampai tahapan neutral. Pada suatu saat kadar hormonnya akan meningkat kembali sesuai dengan kondisi lingkungan dan kemampuan metabolisme makanan yang memacu peningkatan kadar hormon (FSH atau LH). Menurut Syachruddin (1998) dan Syachruddin (2002), peningkatan kadar FSH akan merangsang gonad kerang mutiara untuk mennghasilkan ovum, atau sebaliknya peningkatan kadar LH akan merangsang gonad kerang mutiara untuk menghasilkan spermia.

Hasil percobaan Reichert dalam Mayes, et al. (1992), dalam menggabungkan $\alpha$-LH dengan $\beta$-LH, efek biologiknya meningkat 4-7 kali lebih kuat dari LH normal. Pemisahannya menggunakan asam propionat, asam thioglucolat dan asam urea kadar kuat, pemisahan itu dilakukan untuk membersihkan preparat LH dari kontaminasi FSH. Hasil uji SteelmenPohley dalam Mayes, et al. (1992), menunjukkan bahwa: pemisahan sub-unit $\mathrm{LH}$, yaitu: antara sub-unit $\alpha-\mathrm{LH}$ dengan sub-unit $\beta$-LH hampir menghilangkan aktivitas LH, dan sub unit yang sangat menentukan adalah sub-unit $\beta$-LH. Jelaslah bahwa sub-unit LH akan kehilangan aktivitas LH, bila sub-unitnya dipisahkan maka tidak akan mempunyai efek biologik, tetapi bila digabungkan maka efek biologiknya akan normal kembali.

LH murni menurut Hafez (1980) dalam Mayes, et al. (1992), dapat diperoleh dari domba, kuda, babi dan manusia dengan cara ekstraksi melalui proses yang sangat sulit, karena selalu ada kontaminasi dengan hormon lain, seperti FSH. Menurut Wada and Wada, (1939) dan Soebadi, 
(1992) jumlahnya sangat sedikit baik dalam jaringan adenohypophysis maupun dalam darah; sangat rapuh, rangkaian asam-asam aminonya mudah putus, sehingga potensinya rendah.

Karbohidrat memegang peranan penting dalam fungsi $\mathrm{LH}$, jika preparat dicampur dengan enzim yang menghancurkan karbohidrat maka preparat akan kehilangan seluruh potensinya sehingga penggunaan LH sebaiknya dilakukan melalui injeksi. Menurut Soebadi (1992), karbohidrat yang sangat penting adalah asam sialat. Pengujian terhadap asam sialat merupakan salah satu cara untuk mengetahui keberadaan LH dalam suatu larutan. Keberadaan asam sialat dalam suatu preparat akan menentukan jenis hormon. Preparat hormon yang tidak mengandung asam sialat fungsi $\mathrm{LH}$ akan hilang sedangkan preparat hormon tidak berubah potensinya berarti mengandung FSH.

Hasil penelitian ini memberikan gambaran bahwa kerang mutiara yang memiliki gamet jantan (spermia) kadar LH yang terkandung dalam cairan gonadnya cukup tinggi $61,533 \mathrm{ppm} / \mathrm{cc}$ sedangkan $\mathrm{LH}$ pada kerang mutiara post-spawning (seminggu setelah pemijahan) kadarnya rata-rata menurun menjadi $52,926 \mathrm{ppm} / \mathrm{cc}$ (Syachruddin, dkk., 2004). Menurut Syachruddin, 2002, dalam waktu satu minggu penurunannya sangat signifikan karena rata-rata mencapai $8,610 \mathrm{ppm} / \mathrm{cc}$ dengan taraf signifikansi yang sangat tinggi $\left(\mathrm{t}_{\text {tabel }}=4,03\right.$ dan $\left.\mathrm{t}_{\text {hitung }}=5,10\right)$ pada taraf signifikan 5\% $(\alpha 0,05)$.

Berdasarkan hasil tersebut dapat disimpulkan bahwa perubahan kadar $\mathrm{LH}$ pada kerang mutiara sejalan dengan perubahan fungsi gonad untuk menghasilkan gamet. Kadar LH yang semakin meningkat akan mengubah fungsi gonad kerang mutiara untuk menghasilkan spermia.
Turunnya LH sebanyak 8,610 ppm/cc selama satu minggu kemungkinan akan terjadi sampai tahap netral (neutral). Penurunan sampai tahap neutral membutuhkan waktu sekitar 75 hari. Peristiwa ini menurut Mulyanto (1987) dan Syachruddin, (1998) merupakan salah satu fenomena yang terjadi pada kerang mutiara atau hewan lainnya yang mengalami pergantian fungsi gonad. Lamanya waktu untuk mencapai keseimbangan kedua hormon yang berperan dalam menentukan arah fungsi gonad (LH atau FSH) pada setiap hewan tidak sama sehingga terjadi pemijahan secara musiman (seasonal gamete) dalam waktu yang berbeda (Syachruddin, 1998). Kerang mutiara di perairan tropis biasanya pemijahan secara massal hanya terjadi sekali dalam setahun untuk setiap induk, yaitu setiap bulan Juni sampai Oktober dan puncaknya terjadi pada bulan Juli dan Agustus (Syachruddin, 1990 dan Syachruddin dkk., 1993). Peristiwa ini menurut Tranter (1958) dan terjadi juga pada kerang mutiara yang ada pada perairan sekitar Australia.

Fenomena yang demikian menunjukkan bahwa kondisi lingkungan (makanan) sangat menentukan untuk mengarahkan fungsi gonad kerang mutiara untuk menghasilkan gamet sepanjang hidupnya, seperti yang diungkapkan oleh Tranter (1958), kondisi lingkungan (makanan) dan Mudasir (1981), kemampuan metabolisme protein yang tinggi sangat berpengaruh terhadap perubahan fungsi gonad paga kerang mutiara, namun hasil penelitian ini lebih spesifik menunjukkan bahwa kadar LH sangat berpengaruh terhadap pertumbuhan dan perkembangan gonad kerang mutiara untuk menghasilkan gamet jantan (spermia). Jumlah makanan dan aktivitas metabolisme yang memungkinkan untuk meningkatnya kadar LH akan memacu kerang mutiara menghasilkan spermia, 
tetapi menurut Motojima (1978) dan Mudasir (1981), jika kondisi lingkungan (makanan) dan kemampuan metabolisme untuk meningkatkan kadar protein dan kadar FSH maka kerang mutiara akan mengarahkan fungsi gonadnya untuk menghasilkan ovum.

Fenomena ini menurut Syachruddin, (1998) merupakan peluang yang paling baik dalam mengarahkan fungsi gonad dan meningkatkan daya reproduksi pada kerang mutiara, terutama untuk jenis Pinctada maxima, karena peningkatan kadar LH dapat mengarahkan fungsi gonad untuk menghasilkan spermia.

\section{SIMPULAN}

Kadar LH (Luteinizing Hormone) saat spawning pada kerang mutiara penghasil spermia cukup tinggi (61,533 ppm/cc), tetapi seminggu setelah pemijahan kadarnya turun menjadi $52,926 \mathrm{ppm} / \mathrm{cc}$. Penurunan kadar LH dalam waktu satu minggu sangat signifikan $\left(t_{\text {tabel }}=4,03\right.$ dan $\left.\mathrm{t}_{\text {hitung }}=5,10\right)$ pada taraf signifikan 5\% ( $\alpha$ $0,05)$, karena rata-rata penurunannya mencapai $8,610 \mathrm{ppm} / \mathrm{cc}$.

\section{DAFTAR PUSTAKA}

Allen, J.A., (1942). True Pearl Shell (Family Pteriidae). In Australian Shell. Georgian house, Melbourne.

Chan, A.R., (1949). Pearl Cultur in Japan. U. S. Departement of Interior Fish and Wildlife Service. Washingthon 25. D.C.

Darma, B., (1988). Siput dan Kerang Indonesia. Sarana Graha. Jakarta.

Herdman, D.A., (1904). Pearl Oyster Fisheries Part II. The Gulf of Manaar. With Supplementary Reports upon the Marine Biology of Ceylon by other Naturalists. Pub. at the Request of the
Colonial Goverment by the Royal Society London.

Mayes., Peter, Rodwell, W. Victor, Granner, dan K. Daryl, (1992). Biokomoa (Harper's Review of Biochemistry). Edisi 20 Alih bahasa: Dr. Iyan Darmawan. Cetakan ke VI. 1992. EGC. Penerbit Buku Kedokteran.

Motojima, S., (1978). Experimental Pearl Oysters of Japan.No.100/62. Pub. by Japan Pearl Exporters Ass.

Mudasir, (1981). Budidaya Tiram mutiara. Diklat Ahli Usaha Perikanan Jakarta.

Mulyanto, (1987). Tehnik Budidaya Laut Tiram mutiara di Indonesia. Jaringan Informasi Perikanan Indonesia. Diterbitkan oleh Direktorat Djenderal Perikanan Indonesia.

Sastry, A.N., (1966). Variation Reproduction of Latitudinally Separated Population Of To Marine Vertebrates. Am. Zool.6. 374-375.

Soebadi, P., 1992. Ilmu Reproduksi Hewan. Hormon Reproduksi. Fakultas Kedokteran Veteriner, Jurusan Reproduksi, IPB. Pen. MSW - Jakarta.

Soemadi (1991). Catatan Untuk Analisis Runut Guna Mengendalikan Cemaran Dan Kontaminan Kimia. Majalah Kimia Indonesia Vol.3 No.1.

Sutrisni., H., (1979). Metodology Research 3. Yayasan Penerbit Fakultas Psikhologi Universitas Gajah Mada Indonesia.

Syachruddin, AR., (1990). Kualitas Biologik, Kimia dan Fisik Perairan Pesisir dan Kaitannya dengan Pertumbuhan Tiram mutiara (Pinctada sp.) di Tanjung Bero Sumbawa. NTB (Tesis S2, UGM Yogyakarta). 
Syachruddin, AR., (1998). Stimulasi

Hormonal untuk Memacu Pemijahan

Kerang Mutiara (Pinctada maxima).
Disertasi untuk memperoleh gelar Doktor pada FPS-Universitas Airlangga Surabaya. 